CORRECTION

\title{
Correction: Parkin-mediated mitophagy as a potential therapeutic target for intervertebral disc degeneration
}

Zengjie Zhang, Tianzhen Xu, Jiaoxiang Chen, Zhenxuan Shao, Ke Wang, Yingchao Yan, Congcong Wu, Jialiang Lin, Haoli Wang, Weiyang Gao, Xiaolei Zhang and Xiangyang Wang

(c) The Author(s) 2021

Cell Death and Disease (2021)12:915; https://doi.org/10.1038/s41419-021-04183-9

Correction to: Cell Death and Disease https://doi.org/10.1038/ s41419-018-1024-9, published online 24 September 2018

The original version of this article unfortunately contained a mistake. In the original version of this Article, the $\beta$-actin in Fig. 1B was shown incorrectly, this was due to an oversight at the typesetting stage. The authors have checked the original raw data and records of the experiments. These corrections do not affect the results and conclusions of this article. The authors would like to apologize for any inconvenience caused. The correct figure is as follows:

\begin{abstract}
(i) Open Access This article is licensed under a Creative Commons Attribution 4.0 International License, which permits use, sharing, adaptation, distribution and reproduction in any medium or format, as long as you give appropriate credit to the original author(s) and the source, provide a link to the Creative Commons license, and indicate if changes were made. The images or other third party material in this article are included in the article's Creative Commons license, unless indicated otherwise in a credit line to the material. If material is not included in the article's Creative Commons license and your intended use is not permitted by statutory regulation or exceeds the permitted use, you will need to obtain permission directly from the copyright holder. To view a copy of this license, visit http://creativecommons org/licenses/by/4.0/.
\end{abstract}

(c) The Author(s) 2021
A

\section{Pfirrmann}

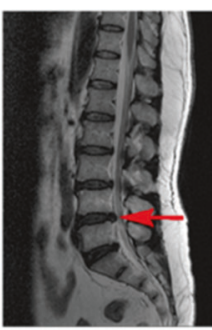

B

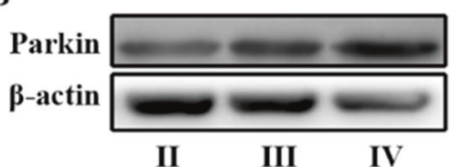

C

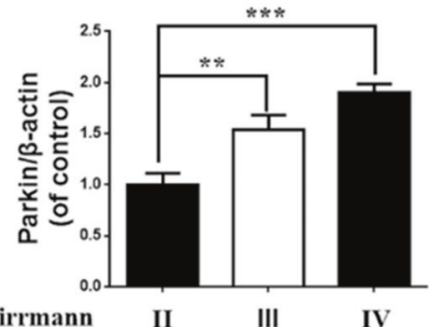

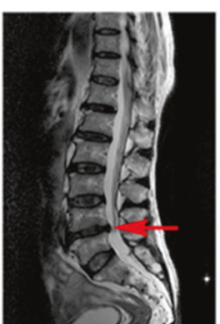

III

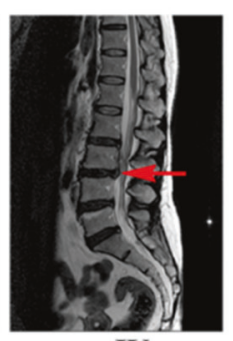

IV

D

Parkin

$\beta$-actin

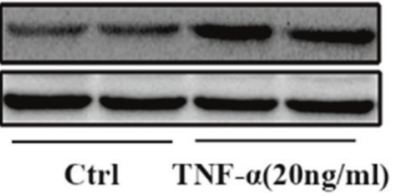

E

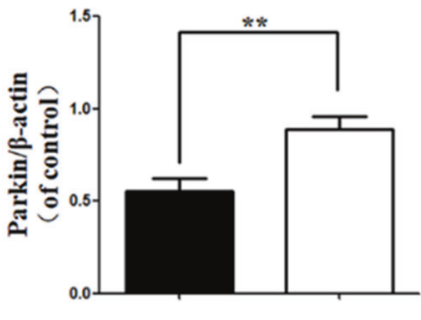

TNF- $\alpha(20 \mathrm{ng} / \mathrm{ml}) \quad 0$

20 